\title{
Optimal anticoagulation in patients with atrial fibrillation and bioprosthetic heart valves
}

\author{
Roberta Bottino ${ }^{1}$, Andreina Carbone1, Biagio Liccardo ${ }^{1}$, Egidio Imbalzano ${ }^{2}$, Antonello D'Andrea ${ }^{3}$, \\ Vincenzo Russo' \\ 'Cardiology Unit, Department of Medical and Translational Sciences, University of Campania "Luigi Vanvitelli" Monaldi Hospital, Naples, Italy \\ ${ }^{2}$ Department of Clinical and Experimental Medicine, University of Messina, Messina, Italy \\ ${ }^{3}$ Department of Cardiology and Intensive Care Unit, Umberto I Hospital, Nocera Inferiore, Salerno, Italy
}

\author{
Correspondence to: \\ Vincenzo Russo, MD, PhD, \\ Cardiology Unit, \\ University of Campania "Luigi \\ Vanvitelli", \\ Monaldi Hospital, \\ Piazzale E Ruggieri 80131, \\ Naples, Italy, \\ phone: +390817065103 \\ e-mail:v.p.russo@libero.it \\ Copyright by the Author(s), 2022 \\ DOI: 10.33963/KP.a2022.0051 \\ Received: \\ February 14, 2022 \\ Accepted: \\ February 16, 2022 \\ Early publication date: \\ February 28, 2022
}

\begin{abstract}
A B S TR A C T
The antithrombotic management of patients after surgical or transcatheter bioprosthetic heart valves (BHVs) replacement is still challenging. Our review aims to describe the current evidence on the best antithrombotic strategy among patients undergoing BHVs replacement (surgical or transcatheter) and/or valve repair, with particular attention to those with atrial fibrillation.

Key words: anticoagulation, antithrombotic therapy, bioprosthetic valves, atrial fibrillation
\end{abstract}

\section{INTRODUCTION}

The general increase in life expectancy leads to a more frequent association between atrial fibrillation (AF) and valvular heart disease (VHD) in clinical practice [1]. It is well established that non-vitamin $\mathrm{K}$ antagonist oral anticoagulants (NOACs) represent the firstline therapy for stroke prevention in patients with non-valvular atrial fibrillation (NVAF) $[2,3]$, whereas vitamin $\mathrm{K}$ antagonists (VKAs) are the only treatment option in patients with mechanical heart valves (MHVs) $[4,5]$. Moreover, NOACs show a better net clinical benefit vs. VKAs among the elderly with AF in a real-world setting [6-10].

The antithrombotic management of patients after bioprosthetic heart valves (BHVs), both surgical and transcatheter, is still challenging. Among patients in need of long-term oral anticoagulation therapy (OAC), such as those with $A F$, there is little evidence from randomized control trials (RCTs) about the best treatment between NOACs or VKAs in those with BHVs [11-13] or transcatheter aortic valve implantation (TAVI) $[14,15]$. Currently, both the European Society of Cardiology/European Association for Cardio-Thoracic Surgery (ESC/EACTS) and American College of Cardi-
ology/American Heart Association (ACC/AHA) guidelines apply few class-I recommendations or level of evidence A to OAC therapy among patients with BHVs $[4,5]$. This review aims to present the current evidence on the best antithrombotic strategy among patients who underwent BHVs replacement (surgical or transcatheter) and/or valve repair, with particular attention to those with AF.

\section{OPTIMAL ANTITHROMBOTIC MANAGEMENT AFTER BHV REPLACEMENT IN THE GENERAL POPULATION}

\section{Surgical mitral and tricuspid BHVs replacement}

Following surgical BHVs replacement, antithrombotic therapy is needed to avoid thromboembolic events, thrombosis of the valve, and subclinical organized valve thrombus complications, which are presumably related to suture material and a sewing ring that is not yet covered with biofilm and endothelialized $[16,17]$. Furthermore, it has been shown that the risk of valve thrombosis and cerebral ischemia is higher in the 180 days after mitral surgery $[16,18,19]$. According to the most re- 
Table 1. Characteristics of the studies exploring the best antithrombotic management after aortic bioprosthetic valve replacement in the general population

\begin{tabular}{|c|c|c|c|c|c|c|}
\hline $\begin{array}{l}\text { Author/ } \\
\text { /reference }\end{array}$ & Study design & $\begin{array}{c}\text { Enrolled } \\
\text { patients, } \\
\mathbf{n}\end{array}$ & $\begin{array}{l}\text { Outcomes } \\
\text { measured }\end{array}$ & FU & $\begin{array}{c}\text { OAC } \\
\text { therapy, } \\
\text { n (\%) }\end{array}$ & $\begin{array}{c}\text { Antiplatelet therapy, } \\
\text { n (\%) }\end{array}$ \\
\hline Sundt et al. [23] & $\begin{array}{l}\text { Retrospective, } \\
\text { VKA vs. no-VKA }\end{array}$ & 1151 & Stroke, bleeding & 90 days & $\begin{array}{l}\text { Warfarin } \\
624(54.2)\end{array}$ & $\begin{array}{c}\text { OAC group } \\
336(53.9) \\
\text { no-OAC group } \\
304(57.7)\end{array}$ \\
\hline $\begin{array}{l}\text { Moinuddeen } \\
\text { et al. [24] }\end{array}$ & $\begin{array}{l}\text { Retrospective, } \\
\text { VKA vs. no-VKA }\end{array}$ & 185 & $\begin{array}{c}\text { Stroke, } \\
\text { bleeding, } \\
\text { RO, HS, SR }\end{array}$ & $>3$ months & $\begin{array}{l}\text { Warfarin } \\
109(58.9)\end{array}$ & $\mathrm{N} / \mathrm{A}$ \\
\hline $\begin{array}{l}\text { Brennan et al. } \\
\text { [25] }\end{array}$ & $\begin{array}{c}\text { Retrospective, } \\
\text { VKA vs. ASA } \\
\text { and } \\
\text { retrospective, } \\
\text { VKA + ASA vs. ASA }\end{array}$ & 25656 & $\begin{array}{l}\text { Death, } \mathrm{TE}^{\mathrm{a}}{ }^{\prime} \\
\text { bleeding }^{\mathrm{b}}\end{array}$ & 3 months & $\begin{array}{c}\text { Warfarin } \\
2999(11.7)\end{array}$ & $\begin{array}{c}\text { ASA } \\
\text { 12457 (48.6) } \\
\text { Warfarin } \\
+ \\
\text { ASA } \\
5972(23.3)\end{array}$ \\
\hline Rafiq et al. [26] & $\begin{array}{c}\text { Prospective, RCT } \\
- \\
\text { BHV-only } \\
\text { subgroup } \\
\text { VKA vs. ASA } \\
\text { and } \\
\text { BHV + CABG subgroup } \\
\text { VKA + ASA vs. ASA }\end{array}$ & 370 & $\begin{array}{l}\mathrm{TE}^{c} \text {, bleeding, } \\
\text { death }\end{array}$ & 3 months & $\begin{array}{c}\text { BHV } \\
\text { subgroup } \\
\text { Warfarin } \\
105(50.2) \\
\text { BHV + CABG } \\
\text { subgroup } \\
\text { Warfarin } \\
63(52.9)\end{array}$ & $\begin{array}{c}\text { BHV } \\
\text { aubgroup } \\
\text { ASA } \\
104(49.8) \\
\text { BHV + CABG } \\
\text { subgroup } \\
\text { ASA } \\
56(47.1)\end{array}$ \\
\hline Mérie et al. [27] & $\begin{array}{l}\text { Retrospective, } \\
\text { VKA vs. no-VKA }\end{array}$ & 4075 & $\begin{array}{l}\text { Stroke, TE, CVM, } \\
\text { bleeding }^{\text {d }}\end{array}$ & $\begin{array}{c}\text { Time periods } \\
\text { (days) } \\
30-89 \\
90-179 \\
365-729 \\
>730\end{array}$ & Warfarine & $\mathrm{N} / \mathrm{A}$ \\
\hline
\end{tabular}

aCerebrovascular accident, transient ischemic attack, and noncerebral arterial thromboembolism; ASA, acetylsalicylic acid; bHemorrhagic stroke, gastrointestinal bleeding, other bleeding; 'Myocardial infarction, stroke, transitory cerebral ischemia, pulmonary embolism, deep vein thrombosis, peripheral arterial embolism,

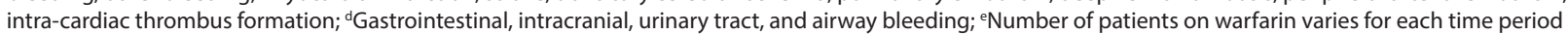
Abbreviations: $\mathrm{BHV}$, bioprosthetic heart valve; $\mathrm{CABG}$, coronary artery by-pass graft; $\mathrm{CVM}$, cardiovascular mortality; FU, follow-up; $\mathrm{HS}$, hospital stay; $\mathrm{n}$, number; $\mathrm{N} / \mathrm{A}$, not available; OAC, oral anticoagulants; RO, repeat operation; SR, survival rate; TE, thromboembolic events; VKA, vitamin-K antagonist

cent guidelines, when there are no other indications for OAC (e.g AF), VKAs therapy is recommended for 3 up to 6 months after mitral and tricuspid BHV surgical replacement [4,5].

\section{Surgical aortic BHVs replacement}

The optimal antithrombotic strategy after surgical aortic BHV replacement is still uncertain $[20,21]$ - because of the low incidence of thromboembolic events following aortic surgery most studies are underpowered to highlight differences between treatment groups [22-24].

While the association therapy with warfarin and aspirin is clearly associated with an increased risk of bleeding $[21,22]$, comparing OAC monotherapy with single antiplatelet therapy (SAPT) has yielded controversial results.

In an observational study including 25656 patients $\geq 65$ years receiving aortic BHV, Brennan et al. [25] showed that warfarin-only therapy seems to have a similar risk of death, embolic events, and bleeding in the 3 months after surgery compared to aspirin-only treatment. On the other hand, in a recent prospective single-center RCT, aspirin was found to be as effective as warfarin in preventing thromboembolic events after BHVs replacement, but with less major bleeding [26].

In a retrospective observational study from the Danish National Patient Registry, including 4075 patients with aortic BHVs replacement discharged on VKA, the discon- tinuation of warfarin treatment within 6 months after BHVs surgery was associated with increased cardiovascular death and with differences in stroke and bleeding events [27]. This result supports the hypothesis of good effectiveness of prolonged (till 6 months) OAC therapy among aortic BHV patients. Tables 1 and 2 summarize the characteristics and results of the above-mentioned studies.

Considering the currently available literature, the 2021 ESC/EACTS guidelines recommend OAC with VKA or aspirin alone for 3 months after the procedure (class lla $B$ ) [4]. In addition, ACC/AHA guidelines suggest lifelong therapy with aspirin in such patients (class Ila $B$ ) even if they were treated with VKA for the first 3 to 6 months after surgery (suggested specifically for low bleeding risk patients, class Ila B) [5].

\section{Transcatheter mitral or aortic BHVs replacement}

\section{Mitral valve}

Little is still known about the optimal antithrombotic strategy among patients undergoing transcatheter mitral $\mathrm{BHV}$ replacement, and no RCTs including these patients are available. Some retrospective observational studies suggest that dual antiplatelet therapy with aspirin plus clopidogrel (DAPT) might be insufficient to avoid post-procedural thrombotic complications $[28,29]$. 
Table 2. Results of the studies analyzing the optimal antithrombotic management after aortic bioprosthetic valve replacement in the general population

\begin{tabular}{|c|c|c|c|}
\hline Author/reference & & Results & \\
\hline \multirow[t]{2}{*}{ Sundt et al. [23] } & Stroke, n (\%) & VKA vs. no-VKA & $\begin{array}{c}16 \text { (2.5) vs. } 9 \text { (1.9) } \\
P=N / A \\
(N S D)\end{array}$ \\
\hline & Bleeding, n (\%) & VKA vs. no-VKA & $\begin{array}{c}\text { Mediastinal } \\
32 \text { (5.0) vs. } 42 \text { (7.4) } \\
\text { Other bleeding } \\
7(1.1) \text { vs. } 4(0.8) \\
\text { P }=\mathrm{N} / \mathrm{A} \\
\text { (NSD) }\end{array}$ \\
\hline \multirow[t]{5}{*}{ Moinuddeen [24] } & Stroke, n (\%) & $\begin{array}{c}\text { VKA vs. no-VKA } \\
\text { Time points } \\
<24 \text { hours; } 24 \text { hours }-3 \mathrm{~m} ;>3 \mathrm{~m}\end{array}$ & $\begin{array}{c}5(4.6), 3 \text { (2.8), and } 12(11) \\
\text { vs. } \\
\begin{array}{c}5(4.6), 3(2.8) \text { and } 12(11) \\
P=N / A \\
(N S D)\end{array}\end{array}$ \\
\hline & Bleeding, n (\%) & VKA vs. no-VKA & $\begin{array}{c}10 \text { (9.2) vs. } 7(9.2) \\
P=N / A \\
(N S D)\end{array}$ \\
\hline & Repeat operation, n (\%) & VKA vs. no-VKA & $\begin{array}{c}6 \text { (5.5) vs. } 7 \text { (9.2) } \\
\mathrm{P}=\mathrm{N} / \mathrm{A} \\
\text { (NSD) }\end{array}$ \\
\hline & Hospital staying (mean) & VKA vs. no-VKA & $\begin{array}{c}12 \text { months both groups } \\
\mathrm{P}=\mathrm{N} / \mathrm{A} \\
\text { (NSD) }\end{array}$ \\
\hline & Survival rates (mean\%) & $\begin{array}{l}\text { VKA vs. no-VKA } \\
\text { Time points } \\
1,5 \text {, and } 7 \text { years }\end{array}$ & $\begin{array}{c}93 \%, 84 \% \text {, and } 62 \% \\
\text { vs. } \\
87 \%, 74 \% \text {, and } 67 \% \\
P=0.60\end{array}$ \\
\hline \multirow[t]{6}{*}{ Brennan [25] } & $\begin{array}{c}\text { Death } \\
\text { ARR }(95 \% \mathrm{Cl})\end{array}$ & $\begin{array}{l}\text { Warfarin } \\
\text { vs. } \\
\text { ASA }\end{array}$ & $1.01(0.80-1.27)$ \\
\hline & & $\begin{array}{c}\text { Warfarin }+ \text { ASA } \\
\text { vs. } \\
\text { ASA }\end{array}$ & $0.80(0.66-0.96)$ \\
\hline & $\begin{array}{c}\text { TE } \\
\operatorname{ARR}(95 \% \mathrm{Cl})\end{array}$ & $\begin{array}{l}\text { Warfarin only } \\
\text { vs. } \\
\text { ASA only }\end{array}$ & $0.95(0.61-1.47)$ \\
\hline & & $\begin{array}{c}\text { Warfarin + ASA } \\
\text { vs. } \\
\text { ASA-only }\end{array}$ & $0.52(0.35-0.76)$ \\
\hline & $\begin{array}{c}\text { Bleeding } \\
\text { ARR }(95 \% \mathrm{CI})\end{array}$ & $\begin{array}{l}\text { Warfarin } \\
\text { vs. } \\
\text { ASA }\end{array}$ & $1.23(0.85-1.79)$ \\
\hline & & $\begin{array}{c}\text { Warfarin }+ \text { ASA } \\
\text { vs. } \\
\text { ASA }\end{array}$ & $2.80(2.18-3.60)$ \\
\hline \multirow[t]{6}{*}{ Rafiq et al. [26] } & $\begin{array}{c}\text { TE } \\
\text { BHV subgroup }\end{array}$ & $\begin{array}{l}\text { Warfarin } \\
\text { vs. } \\
\text { ASA }\end{array}$ & $\begin{array}{c}4(3.8 \%) \text { vs. } 3(2.9 \%) \\
P=0.721\end{array}$ \\
\hline & $\begin{array}{c}\text { TE } \\
B H V+C A B G \text { subgroup }\end{array}$ & $\begin{array}{c}\text { Warfarin }+ \text { ASA } \\
\text { vs. } \\
\text { ASA }\end{array}$ & $\begin{array}{c}7(11.1 \%) \text { vs. } 9(16.1 \%) \\
P=0.592\end{array}$ \\
\hline & $\begin{array}{l}\text { Bleeding } \\
\text { BHV subgroup }\end{array}$ & $\begin{array}{l}\text { Warfarin } \\
\text { vs. } \\
\text { ASA }\end{array}$ & $\begin{array}{c}3(2.9 \%) \text { vs. } 2(2.9 \%) \\
P=0.683\end{array}$ \\
\hline & BHV + CABG subgroup & $\begin{array}{c}\text { Warfarin }+ \text { ASA } \\
\text { vs. } \\
\text { ASA }\end{array}$ & $\begin{array}{c}6(9.5 \%) \text { vs. } 1(1.8 \%) \\
P=0.117\end{array}$ \\
\hline & $\begin{array}{c}\text { Death } \\
\text { BHV subgroup }\end{array}$ & $\begin{array}{l}\text { Warfarin } \\
\text { vs. } \\
\text { ASA }\end{array}$ & $\begin{array}{c}4(3.8 \%) \text { vs. } 3(2.9 \%) \\
P=0.721\end{array}$ \\
\hline & $\begin{array}{c}\text { Death } \\
B H V+C A B G \text { subgroup }\end{array}$ & $\begin{array}{c}\text { Warfarin + ASA } \\
\text { vs. } \\
\text { ASA }\end{array}$ & $\begin{array}{c}4(6.3 \%) 3(5.4 \%) \\
P=0.800\end{array}$ \\
\hline
\end{tabular}


Table 2 (cont.). Results of the studies analyzing the optimal antithrombotic management after aortic bioprosthetic valve replacement in the general population

\begin{tabular}{|c|c|c|c|}
\hline Author/reference & \multicolumn{3}{|c|}{ Results } \\
\hline \multirow[t]{7}{*}{ Mérie et al. [27] } & $\begin{array}{c}\text { Stroke } \\
\text { Event rate }(95 \% \mathrm{Cl})\end{array}$ & $\begin{array}{c}\text { No-VKA vs. VKA } \\
\text { Time period (days) } \\
30-89\end{array}$ & $\begin{array}{c}7(4.07-12.06) \\
\text { vs. } \\
2.69(1.49-4.87) \\
\text { AIRR }(95 \% \mathrm{CI}) \\
2.46(1.09-5.55) \\
P=0.03\end{array}$ \\
\hline & $\begin{array}{c}\text { TE events } \\
\text { Event rate }(95 \% \mathrm{Cl})\end{array}$ & $\begin{array}{c}\text { No-VKA vs. VKA } \\
\text { Time period (days) } \\
\text { 30-89 }\end{array}$ & $\begin{array}{c}13.07(8.76-19.50) \\
\text { vs. } \\
3.97(2.43-6.48) \\
\text { AIRR }(95 \% \mathrm{Cl}) \\
2.93(1.54-5.55) \\
P<0.001\end{array}$ \\
\hline & & $\begin{array}{c}\text { No-VKA vs. VKA } \\
\text { Time period, days, } 90-179\end{array}$ & $\begin{array}{c}5.04(3.43-7.40) \\
\text { vs. } \\
1.87(0.84-4.16) \\
\text { AIRR }(95 \% \mathrm{Cl}) \\
2.65(1.08-6.51) \\
P=0.03\end{array}$ \\
\hline & $\begin{array}{c}\text { CV mortality } \\
\text { Event rate }(95 \% \mathrm{Cl})\end{array}$ & $\begin{array}{l}\text { No-VKA vs. VKA } \\
\text { Time period, days, } \\
30-89\end{array}$ & $\begin{array}{c}31.74(24.69-40.70) \\
\text { vs. } \\
3.97(2.43-6.48) \\
\text { AIRR }(95 \% \mathrm{Cl}) \\
7.61(4.37-13.26) \\
P<0.001\end{array}$ \\
\hline & & $\begin{array}{l}\text { No-VKA vs. VKA } \\
\text { Time period, days, } \\
90-179\end{array}$ & $\begin{array}{c}6.50(4.67-9.06) \\
\text { vs. } \\
2.08(0.99-4.36) \\
\text { AIRR }(95 \% \mathrm{Cl}) \\
3.51(1.54-8.03) \\
P=0.003\end{array}$ \\
\hline & & $\begin{array}{l}\text { Time period, days, } \\
180-364\end{array}$ & $\begin{array}{c}3.07(2.27-4.16) \\
\text { vs. } \\
0.65(0.16-2.61) \\
\text { AIRR }(95 \% \mathrm{Cl}) \\
4.57(1.09-19.13) \\
P=0.04\end{array}$ \\
\hline & $\begin{array}{c}\text { Bleeding } \\
\text { Event rate }(95 \% \mathrm{Cl})\end{array}$ & $\begin{array}{c}\text { No-VKA vs. VKA } \\
\text { Time perio, days, } \\
30-89\end{array}$ & $\begin{array}{c}11.86(7.81-18.01) \\
\text { vs. } \\
5.37(3.54-8.16) \\
\text { AIRR }(95 \% \mathrm{Cl}) \\
2.32(1.28-4.22) \\
P=0.006\end{array}$ \\
\hline
\end{tabular}

Abbreviations: AIRR, adjusted incidence rate ratio; ARR, adjusted relative risk; $\mathrm{Cl}$, confidential interval; NSD, non-significant difference; other — see Table 1

A state-of-the-art review by Pagnesi et al. [30] suggests considering an anticoagulation-based antithrombotic strategy to prevent the risk of valve thrombosis and thromboembolic events after any transcatheter mitral valve replacement procedure (valve-in-valve or valve-in-ring).

The current guidelines are limited by these uncertainties; however, they suggest a VKA prescription for 3 months following the transcatheter mitral intervention as it is the most common strategy applied in clinical practice [4].

\section{Aortic valve}

In the historical trials evaluating TAVI for severe aortic stenosis, a 6-month DAPT strategy following the procedure was used [31, 32]; so, until 2017, this approach was recommended by guidelines (Ila, level of evidence C) [33]. Several observational studies [30-34] and RCTs [35-37] demonstrated a better clinical safety profile of SAPT compared to DAPT, with no significant differences in terms of efficacy among TAVI patients.
In a pooled cohort of 4832 patients discharged with or without OAC after aortic BHV implantation (3889 TAVI and 943 surgical aortic BHV) [42], Chakravarty et al. showed a lower incidence of increased mean valvular gradient, over the first year after the procedure, among patients on OAC (mainly warfarin), with no significant differences in the stroke rate. In patients without an established indication for OAC after successful TAVI, a treatment strategy with aspirin and rivaroxaban $10 \mathrm{mg}$ daily was associated with a higher risk of death or thromboembolic complications and a higher risk of bleeding than with the DAPT strategy [41].

The latest European and American guidelines recommend lifelong SAPT with aspirin after TAVI in patients with no baseline indications for OAC (Class I A and Ila B, respectively) [4, 5]. Moreover, American guidelines approve DAPT or VKA strategy in low bleeding risk patients (class IIb B) [5]. 
Table 3. Results of the studies analyzing the clinical performance of non-vitamin $\mathrm{K}$ oral anticoagulants after bioprosthetic valve implantation in the general population

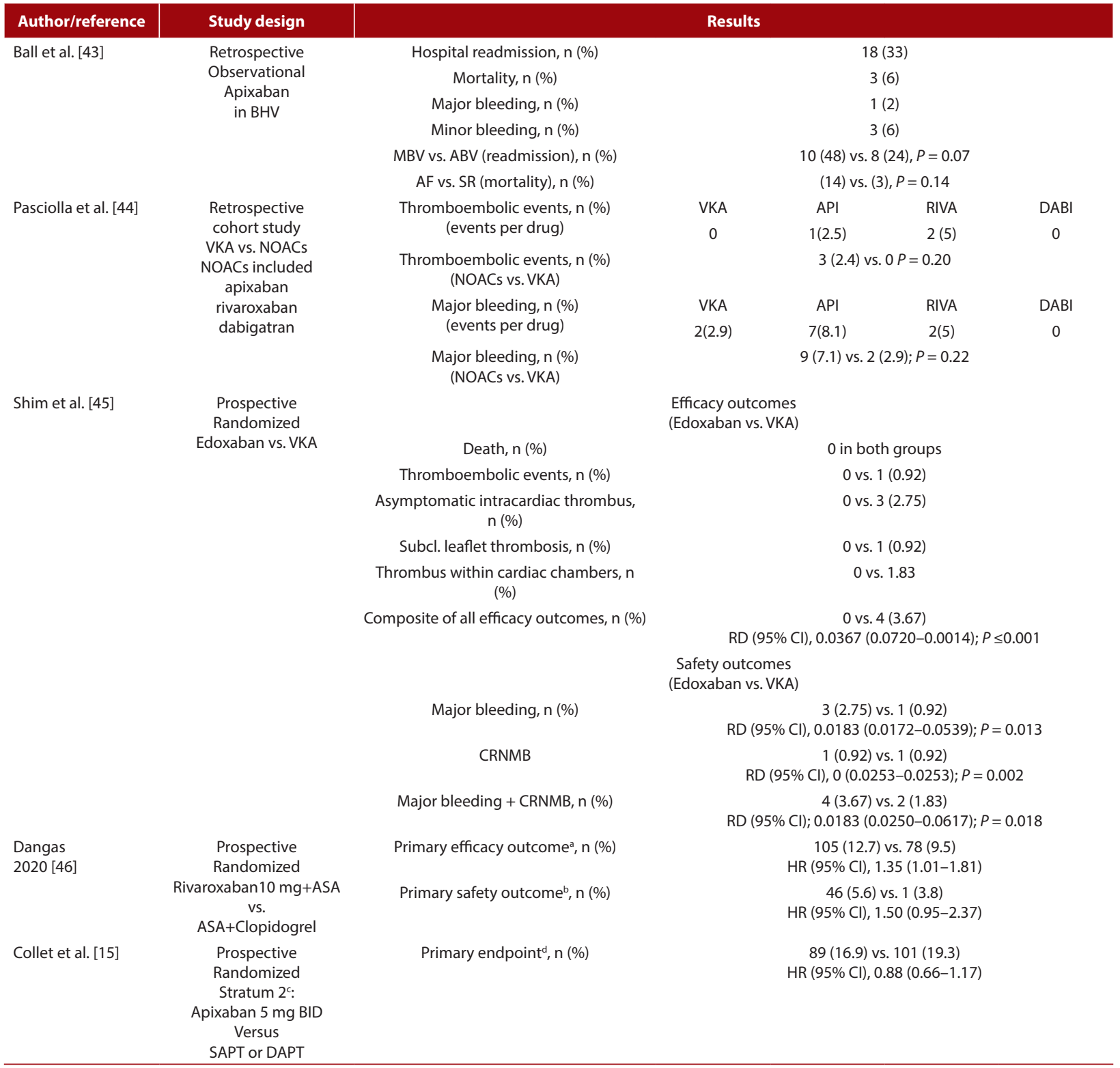

aComposite of death from any cause or thromboembolic events, including any stroke, myocardial infarction, symptomatic valve thrombosis, systemic embolism (not involving the central nervous system), deep-vein thrombosis, or pulmonary embolism; ${ }^{b}$ Composite of life-threatening, disabling, or major bleeding; ${ }^{c}$ Patients with no indication to oral anticoagulation; ${ }^{\mathrm{d} C o m p o s i t e ~ o f ~ a l l-c a u s e ~ d e a t h, ~ s t r o k e, ~ h e a r t ~ a t t a c k, ~ v a l v e ~ t h r o m b o s i s, ~ p u l m o n a r y ~ o r ~ s y s t e m i c ~ e m b o l i s m, ~ d e e p ~ v e i n ~ t h r o m b o s i s ~ o r ~ m a j o r ~ b l e e d i n g ~}$

Abbreviations: $A B V$, aortic bioprosthetic valve; $A F$, atrial fibrillation; $C R N M B$, clinically relevant non-major bleeding; $H R$, hazard ratio; $M B V$, mitral bioprosthetic valve; NOACs, non-vitamin K antagonist oral anticoagulants; Subcl, subclinical; RD, risk difference; SR, sinus rhythm; other — see Tables 1 and 2

\section{NOACs after surgical or transcatheter BHV replacement}

\section{Surgical BHV replacement}

Current guidelines do not recommend the use of NOACs over VKAs when OAC is the preferred antithrombotic strategy after surgical $B H V$ s replacement, especially in patients without AF $[4,5]$. However, some data are being collected on the clinical performance of NOACs in patients with $\mathrm{BHVs}$ or previous valve repair, irrespective of the presence of a long-term indication for OAC (Table 3).

In a small single-center retrospective study [43] including 54 patients undergoing a BHV replacement $(61 \%$ aortic, 39\% mitral), the standard dose of apixaban was safe and well-tolerated with low incidences of major/minor bleeding and thrombotic events. The subgroup analysis comparing patients with and without AF showed a trend toward increased mortality in patients with $A F$, but results did not reach statistical significance ( $14 \%$ vs. $3 \% ; P=0.135)$.

In a small exploratory study including 197 patients undergoing BHV replacement (68\% aortic, 21\% mitral, 11\% both aortic and mitral), Pasciolla et al. [44] evaluated the efficacy and safety of NOACs ( $n=127,64 \%)$ vs. warfarin $(n=70,35.5 \%)$. Eighty-six patients received apixaban, 40 rivaroxaban and 1 dabigatran. More than half (51.8\%) of the study population had a history of AF (NOACs, $n=57$ and 
VKAs, $\mathrm{n}=45)$. The authors found a similar rate of thromboembolic complications ( $2.4 \%$ vs. $0 \%$; $P=0.20$ ) and major bleeding events $(7.1 \%$ vs. $2.9 \% ; P=0.22)$ in the two groups.

The favorable results of observational studies were recently confirmed in the Explore the Efficacy and Safety of Edoxaban in Patients after Heart Valve Repair or Bioprosthetic Valve Replacement (ENAVLE) study [45], a prospective RCT exploring the effectiveness and safety of edoxaban for the first 3 months after surgical aortic and mitral BHV implantation and mitral repair. The study enrolled 218 patients (109 per group). Edoxaban was non-inferior to warfarin for preventing thromboembolism (risk difference -0.0367; $P<0.001)$ and potentially comparable for the risk of major bleeding (risk difference $0.0183 ; P=0.013$ ) during the first 3 months after surgical BHV implantation or valve repair.

\section{TAVI}

Among patients undergoing TAVI, the results of RCTs do not favor a NOAC treatment-based strategy over the antiplatelet therapy. In the Global Study Comparing a rivAroxaban-based Antithrombotic Strategy to an antipLatelet-based Strategy After Transcatheter aortlc vaLve rEplacement to Optimize Clinical Outcomes (GALILEO) trial, rivaroxaban $10 \mathrm{mg}$ daily plus aspirin was compared to DAPT in TAVI patients with no indication to long-term OAC treatment. The study was prematurely terminated because of safety concerns. Indeed, after 17 months of follow-up, the composite endpoint of death or thromboembolic events (hazard ratio $[\mathrm{HR}], 1.53 ; P=0.04$ ), as well as major bleeding events (HR, 1.50; $P=0.08$ ), were found higher in the rivaroxaban group [46].

Similar results were shown by the Anti-Thrombotic Strategy AfterTrans-Aortic Valve Implantation for Aortic Stenosis (ATLANTIS) trial which compared apixaban $5 \mathrm{mg}$ twice daily to aspirin alone or DAPT after TAVI (stratum 2 - no indication for long term OAC) [15]. At one year follow-up, no significant difference in the primary efficacy endpoints was shown (Table 3). However, the authors found higher numbers of secondary endpoints including death, stroke, heart attack, or systemic embolism in the apixaban group.

In summary, among patients undergoing surgical BHV replacement, NOACs can be at least as effective and safe as warfarin. However, in the clinical setting of patients with TAVI, due to the unfavorable results of the GALILEO and ATLANTIS trials, the ESC/EACTS guidelines contraindicated the routine use of OAC in TAVI patients without baseline indication to long term OAC (class III B) and the American guidelines specifically warrant the use of NOACs in these patients $[4,5]$.

\section{ORAL ANTICOAGULATION IN AF PATIENTS WITH BHVS REPLACEMENT}

Patients with $\mathrm{AF}$ and $\mathrm{BHV}$ s have a non-significantly higher risk of thromboembolic events compared to those with $A F$ only. However, in BHV patients with AF, the VKA use is inde- pendently associated with a lower risk of thromboembolic events (HR, 0.83; $P=0.03$ ) [47]. The optimal OAC therapy in AF patients with BHVs is still debated. According to the current guidelines [4], life-long therapy with OAC is recommended for AF patients undergoing BHVs replacement (class IC). Moreover, NOACs may be used as an alternative to VKA only after 3 months from the BHV replacement among AF patients with different classes of recommendation $[4,5]$. Considering the results of the Rlvaroxaban for Valvular heart diseasE and atRial fibrillation (RIVER) trial [13], according to the ESC/EACTS guidelines, NOACs may be considered over VKA also in the first three months following surgical BHV implantation in mitral position in patients with AF (class Ilb C) [4].

\section{NOACs in AF patients with BHVs replacement: preliminary studies}

Two preliminary studies $[44,45]$ reported the clinical performance of NOACs in AF patients with BHVs replacement or valve repair.

In a retrospective single-center cohort study including 73 AF patients undergoing aortic $(n=61)$ or mitral $(n=12)$ BHV replacement, Yadlapati et al. [48] collected data on thromboembolic and major bleeding events during NOAC therapy (dabigatran, $n=44$; rivaroxaban, $n=25$; apixaban, $n=4)$. During the follow-up period of $511.8 \pm 400.8$ days, they recorded 1 transient ischemic attack (TIA; 1.4\%), 5 major bleeding (6.9\%), and 6 minor bleeding (8.2\%) events, 1 hemorrhagic stroke, and 3 deaths (4.1\%). Based on these results, the authors concluded that NOACs therapy appears effective in the prevention of thromboembolic events, albeit at the expense of increased bleeding. However, it is worth mentioning that $72 \%$ of the study population was taking concomitant aspirin treatment [48].

In a retrospective multicenter observational study including $122 \mathrm{AF}$ patients with a prior BHV replacement or valve repair, Russo et al. [49] investigated the incidence of thromboembolic and major bleeding events with NOAC treatment. Patients were treated with apixaban (53.1\%), dabigatran (31\%), or rivaroxaban (15.5\%). During a follow-up of $835 \pm 203$ days, 2 patients (1.7\%) experienced thromboembolic events, and 4 patients (3.3\%) had major bleeding events. The authors concluded that NOACs seem to be an effective and safe alternative therapy in patients with $\mathrm{BHVs}$ replacement or valve repair. Notably, only $20 \%$ of patients were under concomitant antiplatelet therapy. Table 4 shows details of the abovementioned studies.

\section{NOACS vs. VKAs in AF patients with BHVs replacement}

Of the 4 major clinical trials comparing NOACs to warfarin in patients with $\mathrm{AF}$ for the prevention of stroke and systemic embolism [50-53], only the Effective Anticoagulation with Factor Xa Next Generation in AF-Thrombolysis in Myocardial Infarction 48 (ENGAGE AF-TIMI 48) trial and the Apixaban 
Table 4. Clinical performance of non-vitamin K antagonist oral anticoagulants after bioprosthetic heart valve replacement

\begin{tabular}{|c|c|c|c|c|c|c|c|}
\hline $\begin{array}{l}\text { First author/ } \\
\text { /reference }\end{array}$ & $\begin{array}{l}\text { Study } \\
\text { design }\end{array}$ & $\begin{array}{c}\text { Number } \\
\text { of } \\
\text { patients }\end{array}$ & $\begin{array}{l}\text { Follow-up, } \\
\text { days }\end{array}$ & NOAC, $n(\%)$ & Procedure, n (\%) & \multicolumn{2}{|c|}{ Results } \\
\hline \multirow[t]{5}{*}{ Yadlapati et al. [48] } & \multirow{5}{*}{$\begin{array}{l}\text { Obs. } \\
\text { Rtsp } \\
\text { SC }\end{array}$} & \multirow[t]{5}{*}{73} & \multirow{5}{*}{$\begin{array}{l}511.8 \\
400.8\end{array}$} & \multirow{5}{*}{$\begin{array}{c}\text { Dabigatran } \\
44(60.3) \\
\text { Rivaroxaban } 25 \text { (34.2) } \\
\text { Apixaban } \\
4(5.5)\end{array}$} & \multirow{5}{*}{$\begin{array}{c}\text { ABV } \\
61(83.6) \\
\text { MBV/MVR } \\
12(16.4)\end{array}$} & TE events & $1 \mathrm{TIA}(1.4)$ \\
\hline & & & & & & Bleeding events & $5 \mathrm{MB}(6.9)$ \\
\hline & & & & & & & $6 \mathrm{MB}(8.2)$ \\
\hline & & & & & & & $2 \mathrm{ICH}(2.7)$ \\
\hline & & & & & & Mortality & $3(4.1)$ \\
\hline \multirow{7}{*}{ Russo et al. [49] } & \multirow{7}{*}{$\begin{array}{l}\text { Obs. } \\
\text { Rtsp } \\
\text { MC }\end{array}$} & \multirow[t]{7}{*}{122} & \multirow[t]{2}{*}{835} & \multirow{7}{*}{$\begin{array}{l}\text { Dabigatran (31) } \\
\text { Rivaroxaban (15.5) } \\
\text { Apixaban (53.1) }\end{array}$} & ABV & TE events & $2(1.7)$ \\
\hline & & & & & $52(43)$ & & M.A.I: $0.8 \%$ \\
\hline & & & \multirow[t]{5}{*}{203} & & MBV & Bleeding events & $4(3.3)$ \\
\hline & & & & & $24(20)$ & & M.A.I: $1.3 \%$ \\
\hline & & & & & $\begin{array}{c}\text { MSR } \\
41(34)\end{array}$ & Mortality & $0(0)$ \\
\hline & & & & & AVR & & \\
\hline & & & & & $5(4)$ & & \\
\hline
\end{tabular}

Abbreviations: AVR, aortic valve repair; M.A.l, mean annual incidence; MC, multicenter; $M B$, major bleeding, mB, minor bleeding; MVR, mitral valve repair; Obs, observational; Rtsp, retrospective; SC, single-center; TIA, transient ischemic attack; other — see Tables 1 and 3

for Reduction in Stroke and Other Thromboembolic Events in AF (ARISTOTLE) trial included AF patients with BHV replacement [51,53].

In a post hoc analysis from the ENGAGE AF-TIMI 48 [53] including $191 \mathrm{AF}$ patients with BHV replacement $(68.6 \% \mathrm{mi}-$ tral; 31.4\% aortic), Carnicelli et al. [54] showed similar rates of stroke/systemic embolism (HR, $0.37 ; P=0.15)$ and major bleeding ( $\mathrm{HR}, 0.5 ; P=0.26)$ compared to warfarin. Moreover, patients on edoxaban showed significantly lower rates of myocardial infarction, stroke, or cardiovascular death (HR, 0.36; $P=0.03)$. The authors concluded that edoxaban appears to be a reasonable alternative to warfarin in $A F$ patients with previous BHV replacement.

No significant differences between apixaban and warfarin were found for any outcome analyzed in the post-hoc analysis of the ARISTOTLE trial [55] including 156 patients with $\mathrm{AF}$ and $\mathrm{BHV}$ s or valve repair (see Tables 5 and 6 for details).

Two multicenter observational studies $[56,57]$ showed a more favorable effect of NOACs over warfarin in AF patients with BHV replacement. In particular, Russo et al. [56] in a propensity score matching study including $260 \mathrm{AF}$ patients with BHVs (130 patients in each treatment group) showed a low rate of major bleeding among the NOACs group leading to a positive $(+1.87)$ net clinical benefit of NOACs over VKAs.

Among 2672 AF patients with BHVs included in a large integrated health care delivery system in California, Duan et al. [57] did not find significant differences between NOACs-users and VKAs-users in terms of thromboembolic events (composite of ischemic stroke, transient ischemic attack, or systemic embolism). Moreover, a lower risk of major bleeding $(\mathrm{HR}, 0.69 ; P<0.001)$ was shown in the NOAC group. These results were consistent across subgroups (dabigatran versus warfarin; aortic versus mitral valve replacement). Tables 5 and 6 show the characteristics and results of the studies. The preliminary results of the observational studies were confirmed in several RCTs [11-13].
The DAWA pilot study [11] was the first trial designed to compare the effectiveness and safety of dabigatran $110 \mathrm{mg}$ twice daily vs. warfarin in patients undergoing mitral and aortic BHV replacement. The primary endpoint was the presence of a newly diagnosed intracardiac thrombus at 90 days; the secondary outcomes were the development of dense spontaneous echo contrast and the incidence of any stroke, myocardial infarction, valve thrombosis, and peripheral embolic events. The study was terminated prematurely because of the low enrollment (34 patients). During the 90 days of follow-up, no significant differences were found either for the primary or secondary outcomes between the groups.

In a recent small trial [12], $50 \mathrm{AF}$ patients undergoing aortic BHV replacement were randomized to receive apixaban ( $n=25$ patients) or warfarin ( $n=25$ patients) in a 1:1 ratio for the first 3 months after surgery. At 3 months follow-up, no valvular dysfunction was recorded; major bleeding events occurred in 3 patients (12\%) among the warfarin group and none in the apixaban group. The only death reported was in the warfarin group early after surgery (9 days) due to massive pericardial bleeding effusion. The authors concluded that apixaban was non-inferior to warfarin in the first 3 months after surgical aortic BHV replacement and safer with respect to major bleeding and death.

The RIVER trial [13] was a large multicenter RCT in which 1005 AF patients undergoing surgical mitral BHV replacement were enrolled and randomized to receive rivaroxaban or warfarin. At twelve months follow-up, no significant differences in the incidence of stroke (3\% vs. $2.4 \%$ ), major bleeding (1.4\% vs. $2.6 \%$ ), or death ( $4 \%$ vs. $4 \%$ ) were reported between rivaroxaban and warfarin. This trial brought solid data on the non-inferiority of rivaroxaban compared to warfarin with respect to the mean time until the occurrence of death, major cardiovascular events, or major bleeding at 12 months in AF patients with mitral BHV replacement.

Tables 7 and 8 summarize RTCs evaluating NOACs vs. VKAs in AF patients with BHVs replacement. 
Table 5. Overview of the studies characteristics comparing non-Vitamin K oral anticoagulants with Vitamin K antagonist oral anticoagulants in AF patients with bioprosthetic valves or prior surgical valve repair

\begin{tabular}{|c|c|c|c|c|c|c|c|}
\hline Author/reference & Study design & $\begin{array}{l}\text { Number of } \\
\text { patients }\end{array}$ & $\begin{array}{c}\text { Mean FU, } \\
\text { years }\end{array}$ & NOAC, n (\%) & $\begin{array}{c}\text { Procedure, } \\
\text { n (\%) }\end{array}$ & \multicolumn{2}{|c|}{ Primary outcomes } \\
\hline \multirow[t]{3}{*}{ Carnicelli et al. [54] } & $\begin{array}{c}\text { Posthoc } \\
\text { analysis } \\
\text { phase III trial }\end{array}$ & 191 & 2.8 & $\begin{array}{c}\text { Edox. } \\
121(63.4)\end{array}$ & $\begin{array}{c}\text { ABV } \\
60(31.4) \\
\text { MBV 131(68.6) }\end{array}$ & $\begin{array}{l}\text { Efficacy out- } \\
\text { come }\end{array}$ & S/SE \\
\hline & & & & & & Safety outcome & $M B$ \\
\hline & & & & & & Other & $\begin{array}{c}\text { Primary net clinical } \\
\text { outcome }(\mathrm{S} / \mathrm{SE}, \mathrm{MB}, \\
\text { death) }\end{array}$ \\
\hline \multirow[t]{2}{*}{ Guimarães et al. [55] } & $\begin{array}{c}\text { Posthoc } \\
\text { analysis } \\
\text { phase III } \\
\text { trial }\end{array}$ & 156 & 1.8 & $\begin{array}{c}\text { Apix. } \\
87(55.8)\end{array}$ & $\begin{array}{c}\text { ABV } \\
73(46.8) \\
\text { MBV } \\
26(16.7) \\
\text { ABV } \\
+ \text { MBV } \\
5(3.2) \\
\text { MVR } \\
50(32.1) \\
\text { AVR } \\
2(1.3)\end{array}$ & $\begin{array}{l}\text { Efficacy } \\
\text { outcome }\end{array}$ & $\begin{array}{l}\text { S/SE } \\
\text { ACS } \\
\text { IS } \\
\text { MI } \\
\text { Death } \\
\text { CVM }\end{array}$ \\
\hline & & & & & & Safety outcome & $\begin{array}{c}\text { MB, } \\
\text { MB/CRNMB } \\
\text { ICH } \\
\text { Gl bleeding } \\
\text { Any bleeding }\end{array}$ \\
\hline \multirow[t]{3}{*}{ Russo et al. [56] } & $\begin{array}{l}\text { Retrosp. } \\
\text { Propensity } \\
\text { S-matched }\end{array}$ & $\begin{array}{c}260 \\
130 \\
\text { for each group }\end{array}$ & 1.1 & $\begin{array}{c}\text { Apix. } \\
72 \text { (55.4) } \\
\text { Rivarox. } \\
39 \text { (30.0) Dabig. } \\
17 \text { (13.1) Edox. } \\
2(1.4)\end{array}$ & $\begin{array}{c}\text { ABV } \\
128(49.2) \\
\text { MBV } \\
132(50.8) \\
\text { ABV } \\
+ \text { MBV } \\
66(25.4)\end{array}$ & $\begin{array}{c}\text { Efficacy out- } \\
\text { come }\end{array}$ & $\begin{array}{l}\text { S/SE } \\
\text { TIA }\end{array}$ \\
\hline & & & & & & Safety outcome & MB \\
\hline & & & & & & Other & $\mathrm{ICH}$ \\
\hline \multirow[t]{2}{*}{ Duan et al. [57] } & $\begin{array}{l}\text { Retrosp. } \\
\text { cohort study }\end{array}$ & 2672 & 2.9 & $\begin{array}{l}\text { Dabig. } \\
362(13.5) \\
\text { Apix. } \\
60(2.2) \\
\text { Rivarox. } \\
17(0.6)\end{array}$ & $\begin{array}{c}\text { ABV } \\
1,724(64.5) \\
\text { MBV } \\
943(35.3) \\
\text { N/A } \\
5(0.2)\end{array}$ & $\begin{array}{l}\text { Efficacy } \\
\text { outcome }\end{array}$ & $\begin{array}{c}\text { Composite of } \\
\text { IS } \\
\text { TIA/SE }\end{array}$ \\
\hline & & & & & & Safety outcome & Composite of $\mathrm{MB}^{\mathrm{a}}$ \\
\hline
\end{tabular}

aGastrointestinal bleeding, intracranial hemorrhage, and bleeding from other sites

Abbreviations: Apix, apixaban; ACS, all-cause stroke; Dabig, dabigatran; Edox, edoxaban; Gl, gastrointestinal; ICH, intracranial hemorrhage; IS, ischemic stroke; MI, myocardial infarction; S-matched, score-matched; S/SE, stroke/systemic embolism; Rivarox, rivaroxaban; other — see Tables 1, 3 and 4

\section{Oral anticoagulation in AF patients with TAVI}

VKA

Results from studies evaluating the role of OAC alone or with an antiplatelet agent after TAVI are controversial. Early observational studies showed an increased bleeding risk with the association therapy of VKAs with SAPT or DAPT, with no differences in the occurrence of thrombotic events [58,59].

A recent subanalysis of the Placement of Aortic Transcatheter Valve II (Partner II) trial and associated registries [60] showed that antiplatelet therapy with (HR, 0.43; $P=0.015)$ or without (HR, $0.32 ; P=0.002) \mathrm{OAC}$ reduced the 2-year risk of stroke among patients with prior AF undergoing TAVI, implicating multifactorial stroke mechanism in these patients.

The POPular TAVI [61] was a randomized trial of clopidogrel in patients undergoing TAVI who were taking oral anticoagulation (warfarin) for appropriate indications. Patients before TAVI were assigned in a 1:1 ratio into two groups: one not receiving clopidogrel $(n=157)$ and the other receiving clopidogrel $(n=156)$ for 3 months. Patients with $\mathrm{OAC}$ alone showed a lower incidence of serious bleeding (relative risk, $0.64 ; P=0.02$ ) than those on OAC plus clopidogrel. No significant differences in death from cardiovascular causes, non-procedure-related bleeding, stroke from any cause, or myocardial infarction were found.

Based on these results, when long-term OAC is indicated, the current guidelines suggest using life-long $O A C$ alone in TAVI patients with AF (class of recommendation I B in the ESC guidelines and IlaB in the American guidelines). To date, VKAs are the first-line treatment within the first 3 months following TAVI; at the end of this period, NOACs can be evaluated as an alternative $[4,5]$.

\section{NOACs}

The role of NOACs in AF patients undergoing TAVI is still uncertain. In a large propensity score matching study involving 962 AF patients undergoing TAVI who were discharged 
Table 6. Results of the studies comparing non-vitamin K oral anticoagulants with vitamin K antagonist oral anticoagulants in atrial fibrillation patients with bioprosthetic valves or surgical valve repair

\begin{tabular}{|c|c|c|c|}
\hline Author/reference & \multicolumn{2}{|c|}{ Events } & $\begin{array}{c}\text { Statistics } \\
\text { (NOACs vs. VKA) }\end{array}$ \\
\hline \multirow[t]{3}{*}{ Carnicelli et al. [54] } & S/SE & $\begin{array}{c}\text { Warfarin }=8 \\
\operatorname{HDE}=3 \\
\operatorname{LDE} n=4\end{array}$ & $\begin{array}{c}\text { HDE vs. warfarin: } \\
\mathrm{HR}, 0.37 ; 95 \% \mathrm{Cl}, 0.10-1.42 ; P=0.15 \\
\mathrm{LDE} \text { vs. warfarin } \\
\mathrm{HR}, 0.53 ; 95 \% \mathrm{Cl}, 0.16-1.78 \\
P=0.31\end{array}$ \\
\hline & MB & $\begin{array}{l}\text { Warfarin }=9 \\
\qquad \begin{array}{c}\mathrm{HDE}=4 \\
\mathrm{LDE}=1\end{array}\end{array}$ & $\begin{array}{c}\text { HDE vs. warfarin: } \\
\text { HR, 0.5; 95\% Cl, } 0.15-1.67 ; P=0.26 \\
\text { LDE vs. warfarin } \\
\text { HR, 0.12; } 95 \% \mathrm{Cl}, 0.01-0.95 ; P=0.045\end{array}$ \\
\hline & $\begin{array}{c}\text { Primary } \\
\text { net clinical outcome }\end{array}$ & $\mathrm{N} / \mathrm{A}$ & $\begin{array}{c}\text { HDE vs. warfarin: } \\
\mathrm{HR}, 0.46 ; 95 \% \mathrm{Cl}, 0.23-0.91 ; P=0.03 \\
\text { LDE vs warfarin } \\
\mathrm{HR}, 0.43 ; 95 \% \mathrm{Cl}, 0.21-0.88 ; P=0.02\end{array}$ \\
\hline \multirow[t]{13}{*}{ Guimarães et al. [55] } & Efficacy outcomes & & Efficacy outcomes \\
\hline & S/SE & $\begin{array}{c}\text { Warfarin }=2 \\
\text { Apixaban }=4\end{array}$ & $\mathrm{HR}, 1.714 ; 95 \% \mathrm{Cl} 0.313-9.372 ; P=0.53$ \\
\hline & ACS & $\begin{array}{c}\text { Warfarin }=2 \\
\text { Apixaban }=4\end{array}$ & $\mathrm{HR}, 1.714,95 \% \mathrm{Cl} 0.313-9.372 ; P=0.53$ \\
\hline & IS & $\begin{array}{c}\text { Warfarin }=1 \\
\text { Apixaban }=4\end{array}$ & $\mathrm{HR}, 3.286,95 \% \mathrm{Cl} 0.37-29.4 ; P=0.29$ \\
\hline & MI & $\begin{array}{c}\text { Warfarin }=1 \\
\text { Apixaban }=1\end{array}$ & $\mathrm{HR}, 0.825,95 \% \mathrm{Cl} 0.367-29.40 ; P=0.29$ \\
\hline & Death & $\begin{array}{c}\text { Warfarin }=6 \\
\text { Apixaban }=7\end{array}$ & $\mathrm{HR}, 1.017,95 \% \mathrm{Cl} 0.341-3.037 ; P=0.98$ \\
\hline & CVM & $\begin{array}{c}\text { Warfarin }=2 \\
\text { Apixaban }=2\end{array}$ & $\mathrm{HR}, 0.827,95 \% \mathrm{Cl} 0.123-6.201 ; P=0.89$ \\
\hline & Safety outcome & & Safety outcome \\
\hline & MB & $\begin{array}{c}\text { Warfarin }=7 \\
\text { Apixaban }=7\end{array}$ & $\mathrm{HR}, 0.882,95 \% \mathrm{Cl} 0.309-2.519 ; P=0.82$ \\
\hline & MB/CRNMB & $\begin{array}{l}\text { Warfarin }=10 \\
\text { Apixaban }=9\end{array}$ & $\mathrm{HR}, 0.781,95 \% \mathrm{Cl} 0.317-1.925 ; P=0.59$ \\
\hline & $\mathrm{ICH}$ & $\begin{array}{l}\text { Warfarin }=2 \\
\text { Apixaban }=1\end{array}$ & $\mathrm{HR}, 0.467,95 \% \mathrm{Cl} 0.042-5.187 ; P=0.54$ \\
\hline & Gl bleeding & $\begin{array}{c}\text { Warfarin }=2 \\
\text { Apixaban }=3\end{array}$ & $\mathrm{HR}, 1.244,95 \% \mathrm{Cl} 0.208-7.448 ; P=0.81$ \\
\hline & Any bleeding & $\begin{array}{c}\text { Warfarin }=28 \\
\text { Apixaban }=30\end{array}$ & $\mathrm{HR}, 0.866,95 \% \mathrm{Cl} 0.517-1.451 ; P=0.59$ \\
\hline \multirow[t]{3}{*}{$\begin{array}{l}\text { Russo } \\
\text { et al. [56] }\end{array}$} & $\begin{array}{l}\text { S/SE } \\
\text { TIA }\end{array}$ & $\begin{array}{c}\mathrm{VKA}=5 \\
\mathrm{NOAC}=3\end{array}$ & $\mathrm{HR}, 0.49,95 \% \mathrm{Cl}, 0.19-1.22 ; P=0.14$ \\
\hline & MB & $\begin{array}{l}\text { VKA }=12 \\
\text { NOAC }=6\end{array}$ & $\mathrm{HR}, 0.59,95 \% \mathrm{Cl}, 0.15-2.4 ; P=0.47$ \\
\hline & $\mathrm{ICH}$ & $\begin{array}{l}\text { VKA }=3 \\
N O A C=1\end{array}$ & $\mathrm{HR}, 0.33,95 \% \mathrm{Cl}, 0.05-2.34 ; P=0.3$ \\
\hline \multirow[t]{2}{*}{$\begin{array}{l}\text { Duan } \\
\text { et al. [57] }\end{array}$} & $\begin{array}{l}\text { Composite of } \\
\text { IS } \\
\text { TIA/SE }\end{array}$ & $\mathrm{N} / \mathrm{A}$ & $\mathrm{HR}, 1.19,95 \% \mathrm{Cl}, 0.96-1.48 ; P=0.106$ \\
\hline & $\begin{array}{c}\text { Composite of } \\
\mathrm{MB}^{\mathrm{a}}\end{array}$ & $\mathrm{N} / \mathrm{A}$ & $\mathrm{HR}, 0.69,95 \% \mathrm{Cl} 0.56-0.85 ; P<0.001$ \\
\hline
\end{tabular}

Abbreviations: $\mathrm{HDE}$, high dose edoxaban; $\mathrm{LDE}$, low dose edoxaban; a: composite of major bleeding including gastrointestinal bleeding, intracranial hemorrhage, and bleeding from other sites; other - see Tables 1, 3-5

on NOACs ( $\mathrm{n}=326 ; 53.7 \%$ rivaroxaban, $39.2 \%$ apixaban, and $7.1 \%$ dabigatran) or warfarin $(n=626)$, Jochheim et al. [62] did not show any significant differences in the primary safety outcomes (bleeding according to the Bleeding Academic Research Consortium) or all-cause mortality between the two groups at 1-year follow-up. However, the incidence of the primary efficacy outcomes (all-cause mortality, myocardial infarction, and any cerebrovascular events) was higher in the NOACs group (21.2\% vs. $15 \%$; $\mathrm{HR}, 1.44 ; P=0.05)$.

Conversely, in the prospective study of Seeger et al. [63], TAVI patients with AF treated with apixaban experienced a significantly lower rate of the safety endpoints (a composite of all-cause mortality, all stroke, life-threatening bleeding, acute kidney injury, coronary obstruction, major vascular complications, and valve dysfunction requiring reintervention) at 30 days follow up ( $13.5 \%$ vs. $30.5 \%$; $P<0.01)$. No significant differences were found in the rate of stroke at 30 days ( $2.1 \%$ vs. $5.3 \% ; P=0.17)$ and 12 months follow-up between treatment groups (1.2\% vs. $2.0 \% ; P=0.73$ ).

Among 2588 patients who underwent TAVI, enrolled in the prospective multicenter observational Optimized Transcatheter Valvular Intervention (OCEAN) study [64], 403 (15.6\%) patients had AF on anticoagulation therapy 
Table 7. Characteristics of randomized clinical trials comparing non-vitamin $\mathrm{K}$ oral anticoagulants with vitamin $\mathrm{K}$ antagonist oral anticoagulants in AF patients with bioprosthetic valves or surgical valve

\begin{tabular}{|c|c|c|c|c|c|}
\hline Author/reference & Study design & Procedure & Study groups & $\begin{array}{l}\text { Number of patients } \\
\text { (NOACs/VKAs) }\end{array}$ & Primary outcomes \\
\hline $\begin{array}{l}\text { Durães } \\
\text { et al. [11] }\end{array}$ & $\begin{array}{c}\text { Phase } 2 \\
\text { RCT } \\
\text { Pilot study } \\
- \\
\text { FU } \\
\text { At } 90 \text { days }\end{array}$ & $\begin{array}{l}A B V=N / A \\
M B V=20\end{array}$ & $\begin{array}{c}\text { Dabigatran } 110 \mathrm{mg} \\
\text { vs. } \\
\text { Warfarin }\end{array}$ & $\begin{array}{c}\text { Overall }=27 \\
\text { Dabigatran }=15 \\
\text { Warfarin }=12\end{array}$ & $\begin{array}{c}\text { New intracardiac } \\
\text { thrombus } \\
\text { (TEE) }\end{array}$ \\
\hline $\begin{array}{l}\text { Piepiorka-Broniecka } \\
\text { et al. [12] }\end{array}$ & $\begin{array}{c}\text { Prospective RCT } \\
- \\
\text { At } 30 \text { days } \\
\text { And } \\
\text { At } 90 \text { days }\end{array}$ & ABV & $\begin{array}{l}\text { Apixaban } \\
\text { vs. } \\
\text { Warfarin }\end{array}$ & $\begin{array}{l}\text { Overall }=50 \\
\text { Apixaban }=25 \\
\text { Warfarin }=25\end{array}$ & $\begin{array}{c}\text { Death } \\
\text { Bleeding } \\
\text { (1 and } 3 \text { months) } \\
\text { BV function } \\
\text { (3 months) }\end{array}$ \\
\hline Guimarães et al. [13] & $\begin{array}{l}\text { Multicenter } \\
\text { RCT } \\
- \\
\text { FU } \\
365 \text { days }\end{array}$ & MBV & $\begin{array}{c}\text { Rivaroxaban } \\
\text { vs. } \\
\text { Warfarin }\end{array}$ & $\begin{array}{c}\text { Overall }=1005 \\
\text { Rivaroxaban }=500 \\
\text { Warfarin }=505\end{array}$ & 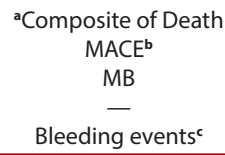 \\
\hline
\end{tabular}

aMean time until a primary-outcome event in days; 'bschemic attack, valve thrombosis, systemic embolism not related to the central nervous system, or hospitalization for heart failure; 'According to the criteria of the Rivaroxaban Once Daily Oral Direct Factor Xa Inhibition compared with Vitamin K Antagonism for Prevention of Stroke and Embolism Trial in Atrial Fibrillation (ROCKET AF): Any bleeding; Major bleeding; Intracranial bleeding; Fatal bleeding; Clinically relevant nonmajor bleeding; Minor bleeding Abbreviations: BV, bioprosthetic valve; RCT: randomized clinical trial; TEE: transesophageal echocardiography; other — see Table 1, 3 and 4.

Table 8. Results of the randomized clinical trials comparing non-vitamin $\mathrm{K}$ oral anticoagulants with vitamin $\mathrm{K}$ antagonist oral anticoagulants in AF patients with bioprosthetic valves or surgical valve

\begin{tabular}{|c|c|c|c|}
\hline Author/reference & \multicolumn{2}{|c|}{ Results (n of events) } & Statistics \\
\hline Durães et al. [11] & $\begin{array}{c}\text { New intracardiac thrombus } \\
\text { (TEE) }\end{array}$ & $\begin{array}{c}\text { Warfarin }=1 \\
\text { Dabigatran }=0\end{array}$ & $\mathrm{RR}, 1.1 ; 95 \% \mathrm{Cl}, 0.9-1.3 ; P=0.42$ \\
\hline \multirow[t]{3}{*}{ Piepiorka-Broniecka et al. [12] } & $\begin{array}{l}\text { Cumulative } \\
\text { death }\end{array}$ & $\begin{array}{l}\text { Warfarin }=1 \\
\text { Apixaban }=0\end{array}$ & $P=0.31$ \\
\hline & $\begin{array}{l}\text { Cumulative } \\
\text { bleeding }\end{array}$ & $\begin{array}{c}\text { Warfarin }=3 \\
\text { Apixaban }=0\end{array}$ & $P=0.07$ \\
\hline & Valve dysfunction & $\begin{array}{l}\text { Warfarin }=0 \\
\text { Apixaban }=0\end{array}$ & $\mathrm{~N} / \mathrm{A}$ \\
\hline \multirow[t]{8}{*}{ Guimarães et al. [13] } & Efficacy outcome & & Efficacy outcome \\
\hline & $\begin{array}{c}{ }^{\text {aCOmposite }} \\
\text { of } \\
\text { Death } \\
\mathrm{MACE}^{\mathrm{b}} \\
\mathrm{MB}^{\mathrm{c}}\end{array}$ & $\begin{array}{c}\text { Warfarin }=340.1 \\
\text { Rivaroxaban }=347.5\end{array}$ & $\begin{array}{c}\text { RMST difference, } \\
7.4 \text { days }(-1.4-16.3) \\
P<0.001 \text { for noninferiority } \\
P=0.10 \text { for superiority }\end{array}$ \\
\hline & Safety outcomes & & Safety outcomes \\
\hline & MB & $\begin{array}{c}\text { Warfarin }=13 \\
\text { Rivaroxaban }=7\end{array}$ & $\mathrm{HR}, 0.54 ; 95 \% 0.21-1.35 ; P=\mathrm{N} / \mathrm{A}$ \\
\hline & $\mathrm{ICH}$ & $\begin{array}{c}\text { Warfarin }=5 \\
\text { Rivaroxaban }=0\end{array}$ & $\mathrm{~N} / \mathrm{A}$ \\
\hline & Fatal bleeding & $\begin{array}{c}\text { Warfarin }=2 \\
\text { Rivaroxaban }=0\end{array}$ & $\mathrm{~N} / \mathrm{A}$ \\
\hline & CRNMB & $\begin{array}{c}\text { Warfarin }=24 \\
\text { Rivaroxaban }=23\end{array}$ & $\mathrm{HR}, 1.05 ; 95 \% \mathrm{Cl}, 0.60-1.87 ; P=\mathrm{N} / \mathrm{A}$ \\
\hline & $\mathrm{mB}$ & $\begin{array}{c}\text { Warfarin }=49 \\
\text { Rivaroxaban }=37\end{array}$ & $\mathrm{HR}, 0.75 ; 95 \% \mathrm{Cl}, 0.49-1.15 ; P=\mathrm{N} / \mathrm{A}$ \\
\hline
\end{tabular}

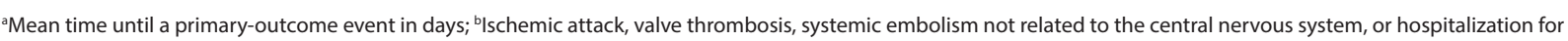
heart failure; 'According to the criteria of the Rivaroxaban Once Daily Oral Direct Factor Xa Inhibition Compared with Vitamin K Antagonism for Prevention of Stroke and Embolism Trial in Atrial Fibrillation (ROCKET AF): Any bleeding; Major bleeding; Intracranial bleeding; Fatal bleeding; Clinically relevant nonmajor bleeding; Minor bleeding Abbreviations: RR, relative risk; RMST, restricted mean survival time; other — see Tables 1-5 and 7

(NOACs, $\mathrm{n}=227 ;$ VKAs, $\mathrm{n}=176$ ). Compared with VKAs, NOACs were associated with a low incidence of all-cause mortality (10.2\% vs. $20.6 \%$; HR, $0.53 ; P=0.036)$ during a median follow-up of 568 days. Similarly, Butt et al. [65] did not find differences in terms of 3-year incidence of arterial thromboembolism, bleeding, or mortality among 219 (29.8\%) AF patients treated with NOACs and $516(70.2 \%)$ treated with VKAs following TAVI.
In the multicenter, prospective, randomized, open-label ENVISAGE-trial [14], edoxaban was non-inferior to VKAs for the efficacy endpoints (composite of death from any cause, myocardial infarction, ischemic stroke, systemic thromboembolism, valve thrombosis) $(\mathrm{HR}, 1.05 ; P=0.01)$ or major bleeding (HR, 1.05; $P=0.01)$. However, it was associated with a higher rate of major bleeding events $(H R$, $1.40 ; P=0.93)$, mainly due to gastrointestinal bleeding. 


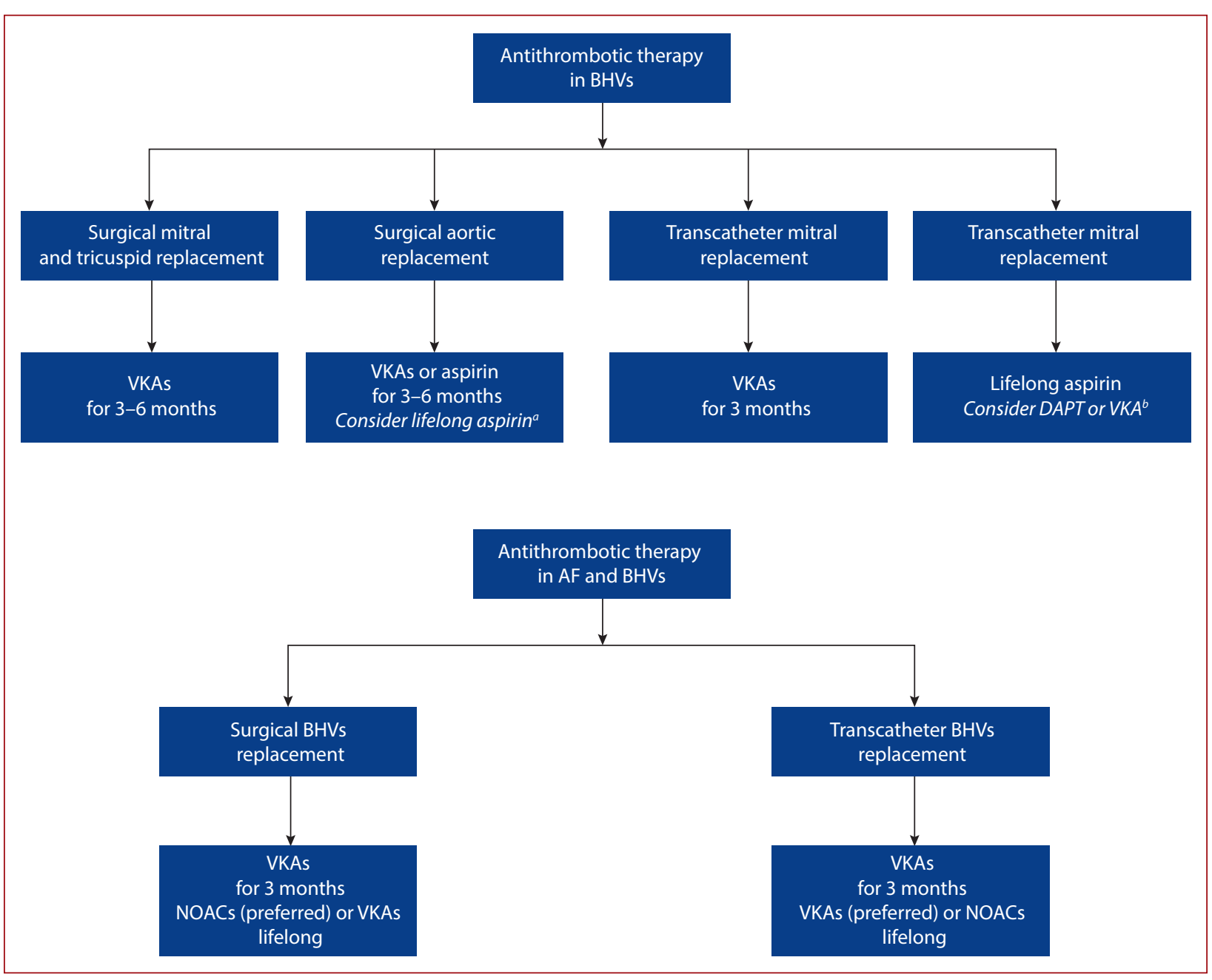

Figure 1. Proposed approach to antithrombotic therapy after bioprosthetic valve replacement aEven in patients treated with VKAs in the first 3-6 months; 'In low bleeding risk patients

Abbreviations: AF, atrial fibrillation, BHVs, bioprosthetic heart valves; DAPT, dual antiplatelet therapy (aspirin plus clopidogrel); NOACs, non-vitamin $\mathrm{K}$ antagonist and anticoagulants; VKA, vitamin $\mathrm{K}$ antagonist oral anticoagulants

On the other hand, in the AF cohort of the ATLANTIS trial (stratum 1) [15], apixaban $5 \mathrm{mg}$ twice daily was found non-inferior for both the primary (composite of all-cause death, stroke, heart attack, valve thrombosis, pulmonary or systemic embolism, deep vein thrombosis or major bleeding; $21.9 \%$ vs. $21.9 \% ; P=\mathrm{NS}$ ) and safety outcomes $(0.9 \%$ vs. $1.3 \% ; P>0.05)$ compared to warfarin.

Even if these preliminary results suggest that NOACs are comparable for the safety profile to VKAs in AF patients undergoing TAVI [47,63-65], some concerns remain about the incidence of adverse ischemic and bleeding events $[14,62]$. Finally, until more data are available, the VKA-based strategy should be preferred early after TAVI in AF patients.

\section{DISCUSSION}

There is increasing evidence that OAC therapy can play a key role in the prevention of early and late thrombotic complications in patients with BHVs, especially in those undergoing mitral or tricuspid replacement $[4,5,16,18,19,66]$.
The optimal duration of OAC therapy is still debated (three or six months). The life-long treatment with aspirin alone is still the standard of care for TAVI patients with no indication for long-term OAC $[4,5]$.

According to the international guidelines $[4,5]$, OACalone therapy is the favored strategy among AF patients undergoing BHVs replacement.

Several studies suggest a preference for NOACs over VKAs among AF patients undergoing surgical BHV replacement [7, 54, 57, 63-65]; however, most of them [48, $49,54,55,57,62-65]$ included patients with concomitant antiplatelet therapy leading to several biases both for thromboembolic and bleeding outcomes. Three recent metanalyses [67-69] support the use of NOACs over VKAs in $\mathrm{AF}$ patients with $\mathrm{BHVs}$, however, the large heterogeneity of the study populations (especially for age and comorbidities) and the inclusion of different valve surgeries make it difficult to generalize the results [67]. Few data support the early use of NOACs even in the first three months [14, 
54, 55]; however, the number of patients randomized in the first 3 months after the procedure is too small to draw definitive conclusions.

Among AF patients undergoing TAVI, the choice of the optimal oral anticoagulant therapy is still uncertain, due to heterogeneous results of the available studies $[4,15$, 62-65]. Moreover, the conflicting results of the ENVISAGE [64] and ATLANTIS trials [46] suggest that comparative RCTs for each NOACs are needed to draw definitive conclusions since the clinical results can vary from one NOAC to another. Figure 1 shows our proposed approach for antithrombotic therapy after both surgical and transcatheter BHV replacement, in light of the data available in the literature.

\section{CONCLUSION}

Finding an optimal oral anticoagulant therapy among patients with BHVs and AF is still challenging. Despite the increasing data suggesting a preference to NOACs over VKAs among AF patients undergoing surgical BHVs replacement, further confirmatory studies are needed to clarify the clinical profile of NOACs among AF patients with BHVs in the first 3 months after intervention and among those with TAVI.

\section{Article information}

Conflict of interest: None declared.

Open access: This article is available in open access under Creative Common Attribution-Non-Commercial-No Derivatives 4.0 International (CC BY-NC-ND 4.0) license, allowing to download articles and share them with others as long as they credit the authors and the publisher, but without permission to change them in any way or use them commercially. For commercial use, please contact the journal office at kardiologiapolska@ptkardio.pl.

\section{REFERENCES}

1. Nkomo V, Gardin J, Skelton T, et al. Burden of valvular heart diseases: a population-based study. Lancet. 2006; 368(9540): 1005-1011, doi: 10.1016/s0140-6736(06)69208-8, indexed in Pubmed: 16980116.

2. Hindricks G, Potpara T, Dagres N, et al. 2020 ESC Guidelines for the diagnosis and management of atrial fibrillation developed in collaboration with the European Association for Cardio-Thoracic Surgery (EACTS): The Task Force for the diagnosis and management of atrial fibrillation of the European Society of Cardiology (ESC) Developed with the special contribution of the European Heart Rhythm Association (EHRA) of the ESC. Eur Heart J. 2021; 42(5): 373-498, doi: 10.1093/eurheartj/ehaa612, indexed in Pubmed: 32860505.

3. Heidenreich PA, Estes NA, Fonarow GC, et al. 2020 Update to the 2016 ACC/AHA Clinical Performance and Quality Measures for Adults With Atrial Fibrillation or Atrial Flutter: A Report of the American College of Cardiology/American Heart Association Task Force on Performance Measures. J Am Coll Cardiol. 2021; 77(3): 326-341, doi: 10.1016/j. jacc.2020.08.037, indexed in Pubmed: 33303319.

4. Vahanian A, Beyersdorf F, Praz F, et al. 2021 ESC/EACTS Guidelines for the management of valvular heart disease. Eur Heart J. 2022; 43(7): 561-632, doi: 10.1093/eurheartj/ehab395, indexed in Pubmed: 34453165.

5. Otto CM, Nishimura RA, Bonow RO, et al. 2020 ACC/AHA Guideline for the Management of Patients With Valvular Heart Disease:A Report of the American College of Cardiology/American Heart Association Joint Committee on Clinical Practice Guidelines. Circulation. 2021; 143(5): e72-e7e227, doi: 10.1161/CIR.0000000000000923, indexed in Pubmed: 33332150.

6. Russo V, Attena E, Mazzone C, et al. Real-life Performance of Edoxaban in Elderly Patients With Atrial Fibrillation: a Multicenter Propensity Score-
Matched Cohort Study. Clin Ther. 2019; 41(8): 1598-1604, doi: 10.1016/j. clinthera.2019.04.041, indexed in Pubmed: 31151813.

7. Russo V, Attena E, Di Maio M, et al. Clinical profile of direct oral anticoagulants versus vitamin $\mathrm{K}$ anticoagulants in octogenarians with atrial fibrillation: a multicentre propensity score matched real-world cohort study. J Thromb Thrombolysis. 2020; 49(1): 42-53, doi: 10.1007/s11239019-01923-9, indexed in Pubmed: 31385163.

8. Russo V, Attena E, Di Maio M, et al. Non-vitamin K vs vitamin K oral anticoagulants in patients aged $>80$ year with atrial fibrillation and low body weight. Eur J Clin Invest. 2020; 50(11): e13335, doi: 10.1111/eci.13335, indexed in Pubmed: 32696449.

9. Russo V, Carbone A, Rago A, et al. Direct oral anticoagulants in octogenarians with atrial fibrillation: it is never too late. J Cardiovasc Pharmacol. 2019; 73(4): 207-214, doi: 10.1097/FJC.0000000000000661, indexed in Pubmed: 30855404.

10. Russo V, Rago A, Proietti R, et al. Efficacy and safety of the target-specific oral anticoagulants for stroke prevention in atrial fibrillation: the real-life evidence. Ther Adv Drug Saf. 2017; 8(2): 67-75, doi: 10.1177/2042098616673990, indexed in Pubmed: 28255434.

11. Durães AR, de Souza Roriz $P$, de Almeida Nunes B, et al. Dabigatran Versus Warfarin After Bioprosthesis Valve Replacement for the Management of Atrial Fibrillation Postoperatively: DAWA Pilot Study. Drugs R D. 2016; 16(2): 149-154, doi: 10.1007/s40268-016-0124-1, indexed in Pubmed: 26892845.

12. Piepiorka-Broniecka M, Michalski TA, Figatowski T, et al. NOAC versus warfarin in the treatment of atrial fibrillation during the first three months after bioprosthetic aortic valve replacement. Cardiol J. 2021 [Epub ahead of print], doi: 10.5603/CJ.a2021.0158, indexed in Pubmed: 34897639.

13. Guimarães HP, Lopes RD, de Barros E Silva PGM, et al. Rivaroxaban in patients with atrial fibrillation and a bioprosthetic mitral valve. $\mathrm{N}$ Engl J Med. 2020; 383(22): 2117-2126, doi: 10.1056/NEJMoa2029603, indexed in Pubmed: 33196155.

14. Van Mieghem NM, Unverdorben M, Hengstenberg C, et al. Edoxaban versus Vitamin K Antagonist for Atrial Fibrillation after TAVR. N Engl J Med. 2021; 385(23): 2150-2160, doi: 10.1056/NEJMoa2111016, indexed in Pubmed: 34449183.

15. Anti-Thrombotic Strategy to Lower All cardiovascular and Neurologic Ischemic and Hemorrhagic Events after Trans-Aortic Valve Implantation for Aortic Stenosis. American College of Cardiology. Available online: www.acc.org/latest-in-cardiology/clinical-trials/2021/05/14/01/58/http\%3a\%2f\%2fwww.acc.org\%2flatest-in-cardiology $\% 2$ fclinical-trials\%2f2021\%2f05\%2f14\%2f01\%2f58\%2fatlantis. (Access: February 4, 2022).

16. Heras $\mathrm{M}$, Chesebro JH, Fuster V, et al. High risk of thromboemboli early after bioprosthetic cardiac valve replacement. J Am Coll Cardiol. 1995; 25(5): 1111-1119, doi: 10.1016/0735-1097(94)00563-6, indexed in Pubmed: 7897124.

17. Roudaut $R$, Serri K, Lafitte $S$. Thrombosis of prosthetic heart valves: diagnosis and therapeutic considerations. Heart. 2007; 93(1): 137-142, doi: 10.1136/hrt.2005.071183, indexed in Pubmed: 17170355.

18. Russo A, Grigioni F, Avierinos JF, et al. Thromboembolic complications after surgical correction of mitral regurgitation incidence, predictors, and clinical implications. J Am Coll Cardiol. 2008; 51(12): 1203-1211, doi: 10.1016/j.jacc.2007.10.058, indexed in Pubmed: 18355659.

19. Butnaru A, Shaheen J, Tzivoni D, et al. Diagnosis and treatment of early bioprosthetic malfunction in the mitral valve position due to thrombus formation. Am J Cardiol. 2013; 112(9): 1439-1444, doi: 10.1016/j.amjcard.2013.06.014, indexed in Pubmed: 23891426.

20. Brueck M, Kramer W, Vogt $P$, et al. Antiplatelet therapy early after bioprosthetic aortic valve replacement is unnecessary in patients without thromboembolic risk factors. Eur J Cardiothorac Surg. 2007; 32(1): 108-112, doi: 10.1016/j.ejcts.2007.03.031, indexed in Pubmed: 17449264.

21. Aramendi Jl, Mestres CA, Mestres CA, et al. Triflusal versus oral anticoagulation for primary prevention of thromboembolism after bioprosthetic valve replacement (trac): prospective, randomized, co-operative trial. Eur J Cardiothorac Surg. 2005; 27(5): 854-860, doi: 10.1016/j.ejcts.2004.12.064, indexed in Pubmed: 15848326.

22. R: The R Project for Statistical Computing. Available online: www.r-project. org/ (Access: January 3, 2022). 
23. Sundt TM, Zehr KJ, Dearani JA, et al. Is early anticoagulation with warfarin necessary after bioprosthetic aortic valve replacement? J Thorac Cardiovasc Surg. 2005; 129(5): 1024-1031, doi: 10.1016/j.jtcvs.2004.11.028, indexed in Pubmed: 15867776.

24. Moinuddeen L, Quin J, Shaw R, et al. Anticoagulation is unnecessary after biological aortic valve replacement. Circulation. 1998; 98(19Suppl): 95-98, indexed in Pubmed: 9852888.

25. Brennan J, Edwards F, Zhao Y, et al. Early anticoagulation of bioprosthetic aortic valves in older patients. J Am Cardiol Coll. 2012; 60(11): 971-977, doi: 10.1016/j.jacc.2012.05.029.

26. Rafiq S, Steinbrüchel DA, Lilleør NB, et al. Antithrombotic therapy after bioprosthetic aortic valve implantation: Warfarin versus aspirin, a randomized controlled trial. Thromb Res. 2017; 150: 104-110, doi: 10.1016/j. thromres.2016.11.021, indexed in Pubmed: 27914653.

27. Mérie $C$, Køber L, Skov Olsen $P$, et al. Association of warfarin therapy duration after bioprosthetic aortic valve replacement with risk of mortality, thromboembolic complications, and bleeding. JAMA. 2012; 308(20): 2118-2125, doi: 10.1001/jama.2012.54506, indexed in Pubmed: 23188028.

28. Hudec V, Bena M, Artemiou P, et al. Reversible thrombotic mitral valve stenosis after transcatheter mitral valve replacement (TMVR): Is life-long anticoagulation therapy necessary? J Card Surg. 2017; 32(3): 190-192, doi: 10.1111/jocs.13109, indexed in Pubmed: 28222495.

29. Eng MH, Greenbaum A, Wang DD, et al. Thrombotic valvular dysfunction with transcatheter mitral interventions for postsurgical failures. Catheter Cardiovasc Interv. 2017; 90(2):321-328, doi: 10.1002/ccd.26909, indexed in Pubmed: 28185392.

30. Pagnesi M, Moroni F, Beneduce A, et al. Thrombotic risk and antithrombotic strategies after transcatheter mitral valve replacement. JACC Cardiovasc Interv. 2019; 12(23): 2388-2401, doi: 10.1016/j.jcin.2019.07.055, indexed in Pubmed: 31806220.

31. Leon MB, Smith CR, Mack M, et al. PARTNER Trial Investigators. Transcatheter aortic-valve implantation for aortic stenosis in patients who cannot undergo surgery. N Engl J Med. 2010; 363(17): 1597-1607, doi: 10.1056/NEJMoa1008232, indexed in Pubmed: 20961243.

32. Leon M, Smith C, Mack M, et al. Transcatheter or surgical aortic-valve replacement in intermediate-risk patients. New Engl J Med. 2016; 374(17) 1609-1620, doi: 10.1056/nejmoa1514616, indexed in Pubmed: 27040324

33. Baumgartner H, Falk V, Baumgartner H, et al. 2017 ESC/EACTS Guidelines for the management of valvular heart disease. Eur Heart J. 2017 38(36): 2739-2791, doi: 10.1093/eurheartj/ehx391, indexed in Pubmed: 28886619.

34. Poliacikova P, Cockburn J, de Belder A, et al. Antiplatelet and antithrombotic treatment after transcatheter aortic valve implantation - comparison of regimes. J Invasive Cardiol. 2013; 25(10): 544-548, indexed in Pubmed: 24088430.

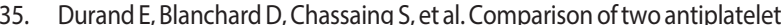
therapy strategies in patients undergoing transcatheter aortic valve implantation. Am J Cardiol. 2014; 113(2): 355-360, doi: 10.1016/j.amjcard.2013.09.033, indexed in Pubmed: 24169016.

36. D'Ascenzo F, Benedetto $U$, Bianco $M$, et al. Which is the best antiaggregant or anticoagulant therapy after TAVI? A propensity-matched analysis from the ITER registry. The management of DAPT after TAVI. Eurolntervention. 2017; 13(12): e1392-e1400, doi: 10.4244/EIJ-D-17-00198, indexed in Pubmed: 28870875.

37. Ichibori Y, Mizote I, Maeda K, et al. Clinical outcomes and bioprosthetic valve function after transcatheter aortic valve implantation under dual antiplatelet therapy vs. Aspirin alone. Circ J. 2017; 81(3): 397-404, doi: 10.1253/circj.CJ-16-0903, indexed in Pubmed: 28123149.

38. Mangieri A, Jabbour RJ, Montalto C, et al. Single-Antiplatelet therapy in patients with contraindication to dual-antiplatelet therapy after transcatheter aortic valve implantation. Am J Cardiol. 2017; 119(7): 1088-1093, doi: 10.1016/j.amjcard.2016.11.065, indexed in Pubmed: 28237287.

39. Ussia GP, Scarabelli $M$, Mulè $M$, et al. Dual antiplatelet therapy versus aspirin alone in patients undergoing transcatheter aortic valve implantation. Am J Cardiol. 2011; 108(12): 1772-1776, doi: 10.1016/j. amjcard.2011.07.049, indexed in Pubmed: 21907949.

40. Rodés-Cabau J, Masson JB, Welsh RC, et al. Aspirin Versus Aspirin Plus Clopidogrel as Antithrombotic Treatment Following Transcatheter Aortic Valve Replacement With a Balloon-Expandable Valve: The ARTE
(Aspirin Versus Aspirin + Clopidogrel Following Transcatheter Aortic Valve Implantation) Randomized Clinical Trial. JACC Cardiovasc Interv. 2017; 10(13): 1357-1365, doi: 10.1016/j.jcin.2017.04.014, indexed in Pubmed: 28527771.

41. Brouwer J, Nijenhuis VJ, Rodés-Cabau J, et al. Antithrombotic therapy in patients undergoing transcatheter aortic valve implantation. Heart. 2019; 105(10): 742-748, doi: 10.1136/heartjnl-2018-314313, indexed in Pubmed: 30867148

42. Chakravarty T, Søndergaard L, Friedman J, et al. Subclinical leaflet thrombosis in surgical and transcatheter bioprosthetic aortic valves: an observational study. Lancet. 2017; 389(10087): 2383-2392, doi: 10.1016/s01406736(17)30757-2, indexed in Pubmed: 28330690.

43. Ball K, Covington EW. Safety and efficacy of apixaban following bioprosthetic valve replacements: a retrospective evaluation. J Pharm Technol. 2021; 37(4): 193-201, doi: 10.1177/87551225211021596, indexed in Pubmed: 34752572

44. Pasciolla S, Zizza LF, Le T, et al. Comparison of the efficacy and safety of direct oral anticoagulants and warfarin after bioprosthetic valve replacements. Clin Drug Investig. 2020; 40(9): 839-845, doi: 10.1007/s40261-02000939-x, indexed in Pubmed: 32607688.

45. Shim CY, Seo J, Kim YJ, et al. Efficacy and safety of edoxaban in patients early after surgical bioprosthetic valve implantation or valve repair: A randomized clinical trial. J Thorac Cardiovasc Surg. 2021 [Epub ahead of print], doi: 10.1016/j.jtcvs.2021.01.127, indexed in Pubmed: 33726903.

46. Dangas GD, De Backer O, Windecker S, et al. A Controlled Trial of Rivaroxaban after Transcatheter Aortic-Valve Replacement. N Engl J Med. 2020; 382(2): 120-129, doi: 10.1056/NEJMoa1911425, indexed in Pubmed: 31733180.

47. Philippart R, Brunet-Bernard A, Clementy N, et al. Oral anticoagulation, stroke and thromboembolism in patients with atrial fibrillation and valve bioprosthesis. The Loire Valley Atrial Fibrillation Project. Thromb Haemost. 2016; 115(5): 1056-1063, doi: 10.1160/TH16-01-0007, indexed in Pubmed: 26843425.

48. Yadlapati A, Groh C, Malaisrie SC, et al. Efficacy and safety of novel oral anticoagulants in patients with bioprosthetic valves. Clin Res Cardiol. 2016; 105(3): 268-272, doi: 10.1007/s00392-015-0919-z, indexed in Pubmed: 26384981

49. Russo V, Attena E, Mazzone C, et al. Nonvitamin K Antagonist Oral Anticoagulants Use in Patients with Atrial Fibrillation and Bioprosthetic Heart Valves/Prior Surgical Valve Repair: A Multicenter Clinical Practice Experience. Semin Thromb Hemost. 2018; 44(4): 364-369, doi: 10.1055/s0037-1615261, indexed in Pubmed: 29304513.

50. Eikelboom JW, Connolly SJ, Brueckmann M, et al. RE-ALIGN Investigators, RE-LY Steering Committee and Investigators. Dabigatran versus warfarin in patients with atrial fibrillation. N Engl J Med. 2009; 361(12): 1139-1151, doi: 10.1056/NEJMoa0905561, indexed in Pubmed: 19717844.

51. Granger CB, Alexander JH, McMurray JJV, et al. Apixaban versus warfarin in patients with atrial fibrillation. N Engl J Med. 2011; 365(11): 981-992, doi: 10.1056/NEJMoa1107039, indexed in Pubmed: 21870978.

52. Patel MR, Mahaffey KW, Garg J, et al. Rivaroxaban versus warfarin in nonvalvular atrial fibrillation. N Engl J Med. 2011; 365(10): 883-891, doi: 10.1056/NEJMoa1009638, indexed in Pubmed: 21830957.

53. Giugliano RP, Ruff CT, Braunwald E, et al. Edoxaban versus warfarin in patients with atrial fibrillation. N Engl J Med. 2013; 369(22): 2093-2104, doi: 10.1056/NEJMoa1310907, indexed in Pubmed: 24251359.

54. Carnicelli AP, De Caterina R, Halperin JL, et al. Edoxaban for the Prevention of Thromboembolism in Patients With Atrial Fibrillation and Bioprosthetic Valves. Circulation. 2017; 135(13): 1273-1275, doi: 10.1161/CIRCULATIONAHA.116.026714, indexed in Pubmed: 28209729.

55. Guimarães PO, Pokorney SD, Lopes RD, et al. Efficacy and safety of apixaban vs warfarin in patients with atrial fibrillation and prior bioprosthetic valve replacement or valve repair: Insights from the ARISTOTLE trial. Clin Cardiol. 2019; 42(5): 568-571, doi: 10.1002/clc.23178, indexed in Pubmed: 30907005

56. Russo V, Carbone A, Attena E, et al. Clinical benefit of direct oral anticoagulants versus vitamin $\mathrm{K}$ antagonists in patients with atrial fibrillation and bioprosthetic heart valves. Clin Ther. 2019; 41(12): 2549-2557, doi: 10.1016/j.clinthera.2019.10.008, indexed in Pubmed: 31735436.

57. Duan L, Doctor JN, Adams JL, et al. Comparison of direct oral anticoagulants versus warfarin in patients with atrial fibrillation and bio- 
prosthetic heart valves. Am J Cardiol. 2021; 146: 22-28, doi: 10.1016/j. amjcard.2021.01.016, indexed in Pubmed: 33529622.

58. Abdul-Jawad Altisent O, Durand E, Muñoz-García AJ, et al. Warfarin and antiplatelet therapy versus warfarin alone for treating patients with atrial fibrillation undergoing transcatheter aortic valve replacement. JACC Cardiovasc Interv. 2016; 9(16): 1706-1717, doi: 10.1016/j.jcin.2016.06.025, indexed in Pubmed: 27539691.

59. Geis NA, Kiriakou C, Chorianopoulos E, et al. Feasibility and safety of vitamin $\mathrm{K}$ antagonist monotherapy in atrial fibrillation patients undergoing transcatheter aortic valve implantation. Eurolntervention. 2017; 12(17): 2058-2066, doi: 10.4244/EIJ-D-15-00259, indexed in Pubmed: 28433958.

60. Kosmidou I, Liu Y, Alu MC, et al. Antithrombotic therapy and cardiovascular outcomes after transcatheter aortic valve replacement in patients with atrial fibrillation. JACC Cardiovasc Interv. 2019; 12(16): 1580-1589, doi: 10.1016/j.jcin.2019.06.001, indexed in Pubmed: 31439338.

61. Brouwer J, Nijenhuis VJ, Rodés-Cabau J, et al. Antithrombotic therapy in patients undergoing transcatheter aortic valve implantation. Heart. 2019; 105(10): 742-748, doi: 10.1136/heartjnl-2018-314313, indexed in Pubmed: 30867148.

62. Jochheim D, Barbanti M, Capretti G, et al. Oral anticoagulant type and outcomes after transcatheter aortic valve replacement. JACC CardiovasC Interv. 2019; 12(16): 1566-1576, doi: 10.1016/j.jcin.2019.03.003, indexed in Pubmed: 31202946.

63. Seeger J, Gonska B, Rodewald C, et al. Apixaban in patients with atrial fibrillation after transfemoral aortic valve replacement. JACC Cardiovasc Interv. 2017; 10(1): 66-74, doi: 10.1016/j.jcin.2016.10.023, indexed in Pubmed: 27916486.
64. Kawashima H, Watanabe $\mathrm{Y}$, Hioki H, et al. Direct Oral Anticoagulants Versus Vitamin K Antagonists in Patients With Atrial Fibrillation After TAVR. JACC Cardiovasc Interv. 2020; 13(22): 2587-2597, doi: 10.1016/j. jcin.2020.09.013, indexed in Pubmed: 33129818.

65. Butt JH, De Backer O, Olesen JB, et al. Vitamin K antagonists vs. direct oral anticoagulants after transcatheter aortic valve implantation in atrial fibrillation. Eur Heart J Cardiovasc Pharmacother. 2021; 7(1): 11-19, doi: 10.1093/ehjcvp/pvz064, indexed in Pubmed: 31665260.

66. Melillo E, Carbone A, Rago A, et al. Update on Direct Oral Anticoagulants in Atrial Fibrillation Patients Undergoing Cardiac Interventional Procedures: From Clinical Trials to Real-World Evidence. J Cardiovasc Pharmacol. 2020; 75(3): 185-199, doi: 10.1097/FJC.0000000000000786, indexed in Pubmed: 31876798.

67. Lacy SC, Saint Croix GR, Porter K, et al. Direct oral anticoagulants in patients with atrial fibrillation and bioprosthetic valve replacement: A meta-analysis. Catheter Cardiovasc Interv. 2021; 98(7): E1007-E1016, doi: 10.1002/ccd.29911, indexed in Pubmed: 34383369.

68. Malik AH, Yandrapalli S, Aronow WS, et al. Oral anticoagulants in atrial fibrillation with valvular heart disease and bioprosthetic heart valves. Heart. 2019; 105(18): 1432-1436, doi: 10.1136/heartjnl-2019-314767, indexed in Pubmed: 31203254.

69. Kheiri B, Przybylowicz R, Simpson TF, et al. Meta-analysis of direct oral anticoagulants in patients with atrial fibrillation and bioprosthetic valves. Am J Cardiol. 2021; 142: 140-141, doi: 10.1016/j.amjcard.2020.12.006, indexed in Pubmed: 33285096. 